\title{
Ethanol Extract of Pinus nigra ssp. pallasiana var. şeneriana Inhibits Human Breast Cancer Cell Viability through Induction of Apoptosis
}

\author{
Harika Atmaca ${ }^{1 *}$, Çisil Çamlı ${ }^{2}$ Seda Sert ${ }^{2}$ \\ ${ }^{1}$ Manisa Celal Bayar University, Faculty of Science and Letters, Biology Department \\ Manisa, +90 236 2012607, harika.atmaca@cbu.edu.tr \\ ${ }^{2}$ Manisa Celal Bayar University, Applied Science Research Center, +90 2362012662 , \\ cisil.camli@cbu.edu.tr; sedayetim35@gmail.com \\ *Corresponding Author
}

Received: 16 August 2017

Accepted: 13 March 2018

DOI: $10.18466 /$ cbayarfbe. 334883

\begin{abstract}
Novel natural compounds became the new promising source for alternative drug production for cancer treatment. Several studies have reported that different species of pine genus show cytotoxic activities against various cancer cell lines. In the present study, the possible cytotoxic and apoptotic effects of the endemic Pinus nigra ssp. pallasiana var. şeneriana (PS) extract in MCF-7 breast cancer cells were evaluated. Cell viability was determined via XTT assay and verified by live/dead viability/cytotoxicity assay. Apoptotic effect was investigated by mitochondrial membrane potential (MMP) assay. Expression of apoptosis related proteins after treatment with PS extract was detected by apoptosis array. PS extract treatment reduced the viability of MCF-7 cells in a time and concentration-dependent manner. Apoptosis was induced and MMP was decreased in MCF-7 cells by $48 \mathrm{~h}$ treatment. Bcl-2, cIAP-1, cIAP-2, Survivin and XIAP protein levels were reduced by 2.8-, 3.2-, 2.8, 2.5- and 2.2- fold, and Bad, Bax, Cytochrome c and SMAC/Diablo protein levels were induced by 4.2-, 3.0-, 3.6-, and 4.0- fold in MCF-7 cells by PS extract treatment. This report describes the cytotoxic and apoptotic effects of the extract of endemic Pinus species on MCF-7 cells for the first time. Although the isolation and structure elucidation of the active compounds is needed to be performed in the further studies, it is likely that PS extract may be a potential candidate for the development of novel therapeutic anticancer compounds for breast cancer.
\end{abstract}

Keywords-Apoptosis, breast cancer, cytotoxicity, Pinus nigra.

\begin{abstract}
1 Introduction
Breast cancer is not only one of the most common cancer type threatening woman health, but also one of the main cause of woman's cancer-related death [1]. Because of the severe side effects of the chemotherapeutic treatments and occurrence of the drug resistance, novel agents and treatment strategies are urgently needed. Nowadays, novel natural compounds became the new promising source for alternative drug production for cancer treatment. Among these natural compounds, plant extracts hold an advantageous place because of the efficiency as well as for their relatively easy accessibility [2].
\end{abstract}

Pine species belonging to Pinus genus, are widely distributed around the world. Different parts of the pine trees, like needles, bark, and cones are used as a food source or for medical purposes [3], [4]. Especially the needles of the pine are known to contain essential amino acids and glutamic acid [5]. Some of the other compounds obtained from pine needles are; $\alpha$-pinene, $\beta$-pinene, myrcene, linalyl acetate, germacrene-D, E-caryophyllne, $\alpha$-humulene and $\delta$-cadinene [6]. Certain bioactive compounds isolated from different Pinus species are used for their antioxidant, antimicrobial, cytotoxic and antitumor activities [5]. The potential cytotoxic activity of the extracts of Pinus genus has been recently described in many studies. The extract of Pinus koraiensis bark, being used as a herbal medicine, was shown to have cytotoxic and apoptotic effect on HeLa cell line [7]. Pycnogenol ${ }^{\circledR}$ is an extract obtained from the bark Pinus maritima, showed to increase the toxic effect of anticancer drugs doxorubicin and cyclophosphamide [8]. Moreover, diterpenes isolated from the needles of Pinus sylvestris was found to be effective against human cervix cancer (HeLa) cells, human neuroblastoma (SK-N- 
$\mathrm{SH}$ ) cells and human hepatocellular carcinoma (BEL7402) cells [9]. In Turkey, five Pinus species, Pinus brutia, Pinus halepensis, Pinus pinea, Pinus sylvestris and Pinus nigra are widely distributed with a number of subspecies. PS is an endemic species of Turkey and its distribution area is known to be around Bolu, Manisa and Kütahya [10]. PS species in Manisa, Alaşehir, Bahadır village was identified by Apltekin (1987), and described with shorter height and smaller needles compared to subspecies pallasiana [11].

The aim of this study was to investigate the possible cytotoxic and apoptotic effects of the PS extract on MCF-7 breast cancer cells.

\section{Materials and Methods}

\subsection{Cell lines and culture}

MCF-7 cell line is purhased from Interlab Cell Line Collection (Genova, Italy). MCF-7 cells were cultured in RPMI 1640 medium containing 10\% fetal bovine serum, $1 \%$ L-glutamine, and $1 \%$ penicillin-streptomycin (Corning Life Sciences). Cells were incubated at $37^{\circ} \mathrm{C}$ in a humidified atmosphere with $5 \% \mathrm{CO}_{2}$. Growth and morphology were monitored every day. Cell culture supplies were obtained from Biochrom (Berlin, Germany).

\subsection{Microwave-assisted extraction (MAE) of the plant material}

The branches of PS with needles on were collected from Bahadır village, Alaşehir, Manisa. Needles were removed from the branches and washed with phosphate buffered saline (PBS). MAE was carried out at the CEM Mars6 Digestion Microwave System (Matthews, USA) equipped with a temperature probe and infrared sensors. $0.6 \mathrm{~g}$ of pine needles taken in a polytetrafluoroethylene vessel and $30 \mathrm{ml}$ ethanol (Sigma-Aldrich Seelze, Germany) was added. The microwave system was programmed to maintain the temperature at $80{ }^{\circ} \mathrm{C}$ for 6 min with a ramp time of $8 \mathrm{~min}$. At the end of incubation, extract of PS was dissolved in $50 \mathrm{ml}$ ethanol.

\subsection{XTT cell viability assay}

Cell number was determined via using trypan blue dye exclusion test with Countess automatic cell counter (Countess, Thermo Fisher Scientific, Massachusetts, USA). Cells were seeded at $1 \times 10^{4}$ cells per well in a 96well flat-bottom plates with a final volume of $200 \mu \mathrm{l}$ and incubated at $37^{\circ} \mathrm{C}$ in a $5 \% \mathrm{CO}_{2}$ incubator for 24 hours. After $24 \mathrm{~h}$ incubation, MCF-7 cells were exposed to increasing concentrations of PS extract (100 to $1000 \mu \mathrm{g} / \mathrm{ml}$ ) for 24, 48, and 72 hours. Media was not refreshed during the incubation time. At the end of the each incubation, 100 $\mu \mathrm{l}$ of XTT (2,3-bis (2-methoxy-4-nitro-5-sulfophenyl)-5 [(phenylamino) carbonyl] $-2 \mathrm{H}$-tetrazolium hydroxide)
(Roche Applied Science, Mannheim, Germany) was added to each well and incubated at $37{ }^{\circ} \mathrm{C}$ incubator for another 4 hours. Absorbance of each well was measured at $450 \mathrm{~nm}$ against a reference wavelength at $650 \mathrm{~nm}$ using a microplate reader (TECAN, Männedorf, Switzerland). $\mathrm{IC}_{25}$ and $\mathrm{IC}_{50}$ values were calculated from the mean of the triplicate experiments.

\subsection{The live/dead viability/cytotoxicity assay}

After calculating the $\mathrm{IC}_{25}$ and $\mathrm{IC}_{50}$ values, Cellstain double staining kit (Sigma-Aldrich, Seelze, Germany) was used to verify the cytotoxic effect of the PS extract. Calcein-AM stains live cells and emits strong green fluorescence whereas propidium iodide (PI) stains dead cells without membrane integrity and emits strong red fluorescence. Cells were seeded in six-well plates at a density of $1 \times 10^{6}$ cells/well in $2 \mathrm{ml}$ culture medium and incubated for $24 \mathrm{~h}$ at $37^{\circ} \mathrm{C}$ in a $\mathrm{CO}_{2}$ incubator for attachment of the cells. After the incubation period, the cells were treated with PS extract for 48 hours. At the end of 48 hours, contents of the wells were removed and wells were washed with PBS for several times. Mixture of $10 \mu \mathrm{l}$ calcein-AM and $5 \mu \mathrm{PI}$ in $1 \mathrm{ml}$ PBS was added to each well and incubated for 15 minutes at $37^{\circ} \mathrm{C}$. The stained cells were observed with a fluorescence microscope (Olympus, Tokyo, Japan).

\subsection{Mitochondrial membrane potential (MMP) assay}

MMP loss was evaluated by tetramethylrhodamine, ethyl ester (TMRE) dye (Cayman Chemicals, Michigan, USA). TMRE is a red-orange membrane permeable dye which accumulates in the active mitochondria because of it's relative negative charge. Depolarized or inactive mitochondria have decreased membrane potential and they do not accumulate TMRE. Cells were seeded at a density of $1 \times 10^{6}$ cells/well and treated with PS extract for 48 hours. At the end of 48 hours, $50 \mu \mathrm{M}$ TMRE solution was added to each well and incubated at $37^{\circ} \mathrm{C}$ for 30 minutes. At the end of incubation time, stained cells were observed with a fluorescence microscope at $549 \mathrm{~nm}$ against a reference wavelength at $575 \mathrm{~nm}$ (Olympus, Hamburg, Germany).

\subsection{Proteome profiler ${ }^{\mathrm{TM}}$ array}

To determine the effects of PS extract on the expression levels of apoptosis related proteins in breast cancer cells, R\&D Human Apoptosis Array Kit (R\&D Systems, Abingdon, OX, UK) was used according to the instruction's manual. The array includes a nitrocellulose membrane coated with specific antibodies for each protein. The samples were added after blocking the membranes for $1 \mathrm{~h}$. Then, the samples were incubated at room temperature for $5 \mathrm{~h}$. After incubation with a biotinylated antibody for $2 \mathrm{~h}$, the arrays were incubated with horseradish peroxidaseconjugated streptavidin for another $2 \mathrm{~h}$. The signals were 
detected using UVP BioSpectrum Imaging System (Cambridge, UK). The spots were quantified by a computerassisted system for image analysis (Koadarray ${ }^{\circledR} 2.6$ software).

\subsection{Statistical analysis}

GraphPad Prism (GraphPad Software, San Diego, USA) was used for data analysis. The data were presented as the means \pm SD. Two-way ANOVA followed by Bonferroni post-tests was applied to determine the significant differences between different treatments. The Student's t-test was applied to determine significant differences between groups. Values with $\mathrm{p}<0.05$ were considered statistically significant.

\section{Results}

First, the effect of PS extract on the cell viability of MCF7 breast cancer cells was determined. For this aim, MCF-7 cells were treated with the increasing concentrations (100$1000 \mu \mathrm{g} / \mathrm{ml}$ ) of PS extract for 24, 48 and $72 \mathrm{~h}$ and then XTT cell viability assay was performed. The PS extract decreased the cell viability of MCF-7 cells in a time- and concentration-dependent manner, as compared to untreated controls (Figure $1 \mathrm{~A}-\mathrm{C})(\mathrm{p}<0.05)$. The $\mathrm{IC}_{50}$ value of PS extract was $560 \mu \mathrm{g} / \mathrm{ml}$ at $48 \mathrm{~h}$ in MCF-7 cells.
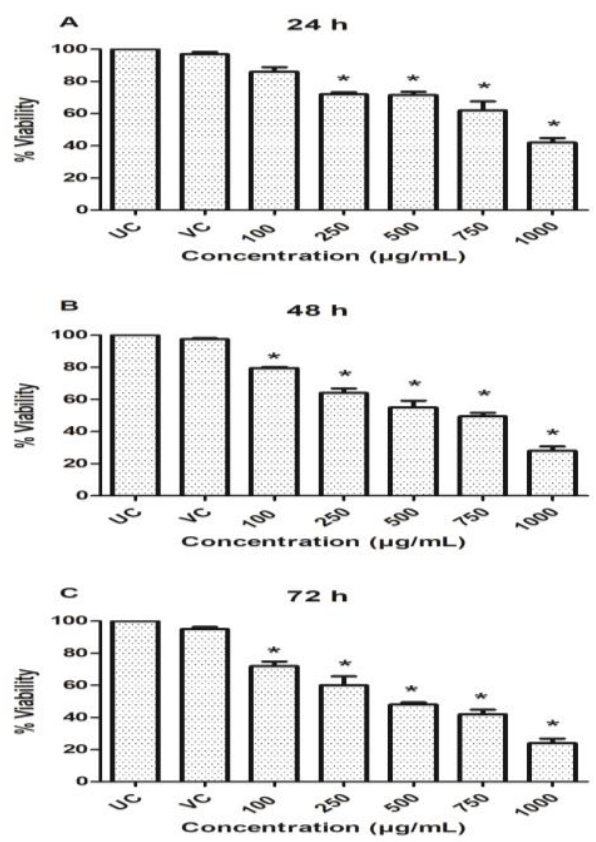

Figure 1: Time and concentration dependent effect of PS extract on the viability of MCF-7 cells $(* \mathrm{P}<0.05$ compared to untreated control, UC: Untreated control, VC: Vehicle control)

As shown in Fig. 1A, there were $14.1 \%, 27.9 \%$ and 29.6 $\%$ decreases in the cell viability of MCF-7 cells exposed to $100,250,500 \mu \mathrm{g} / \mathrm{ml}$ of extract, respectively, as compared to untreated controls at $24 \mathrm{~h}(\mathrm{p}<0.05)$. There were $19.2 \%, 36.1 \%$ and $47.1 \%$ decreases in the cell viability of MCF-7 cells exposed to $100,250,500 \mu \mathrm{g} / \mathrm{ml}$ of extract, respectively, as compared to untreated controls at $48 \mathrm{~h}$ $(\mathrm{p}<0.05)$. Treatment of MCF-7 cells to 100, 250, 500 $\mu \mathrm{g} / \mathrm{ml}$ of extract for $72 \mathrm{~h}$ resulted in $28.2 \%, 39.9 \%$ and $53.2 \%$ decreases in the cell viability, respectively $(\mathrm{p}<0.05)$. To verify the cytotoxic effect of PS extract, live/dead cell viability assay was also performed. As shown in Figure 2 (A-C), the number of attached cells was decreased by the increasing concentrations of PS extract. The number of dead cells (red stained) was also increased by $160 \mu \mathrm{g} / \mathrm{ml}$ PS extract treatment, as compared to the untreated cells. However, the number of dead cells was higher in $560 \mu \mathrm{g} / \mathrm{ml}$ PS extract treated MCF-7 cells (Figure 2C).
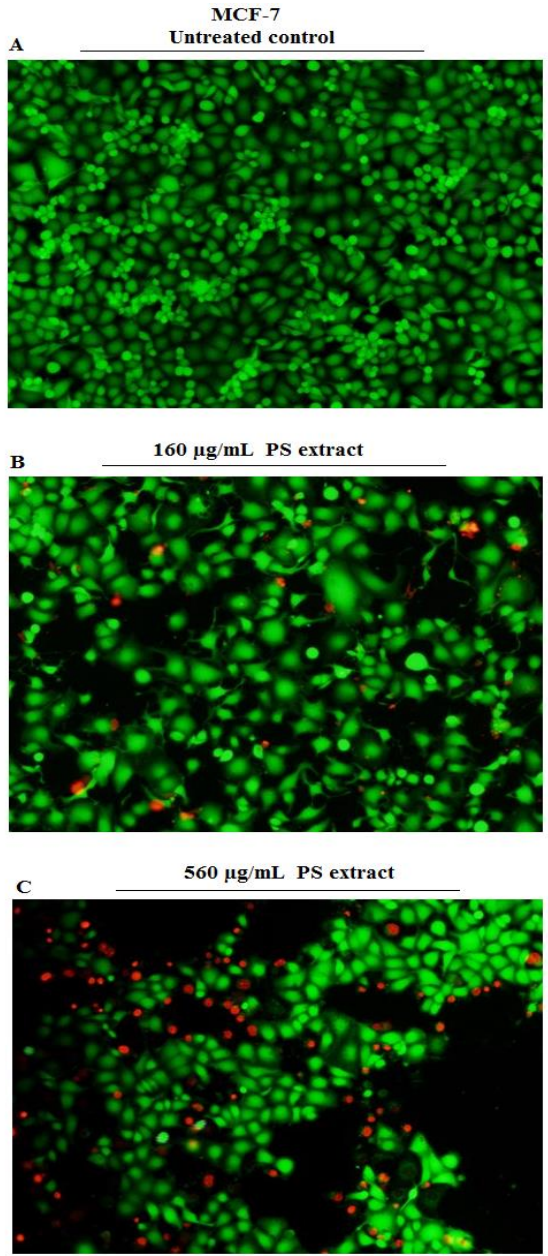

Figure 2: Images of MCF-7 cells stained with live/dead cell reagent after treatment with $160 \mu \mathrm{g} / \mathrm{ml}$ and $560 \mu \mathrm{g} / \mathrm{ml}$ PS extract. The red and green fluorescence are the markers of dead and live cells, respectively. The cell death was increased by PS extract treatment when compared to untreated control. 
To determine whether PS extract can induce apoptosis in breast cancer cells, cells were treated with different concentrations of PS extract for $48 \mathrm{~h}$ and then MMP was evaluated. As seen in Figure 3 (A-C), PS extract treatment decreased the MMP in MCF-7 cells, indicating a possible apoptotic effect, at both $160 \mu \mathrm{g} / \mathrm{ml}$ and $560 \mu \mathrm{g} / \mathrm{ml}$ concentrations, as compared to untreated control cells.
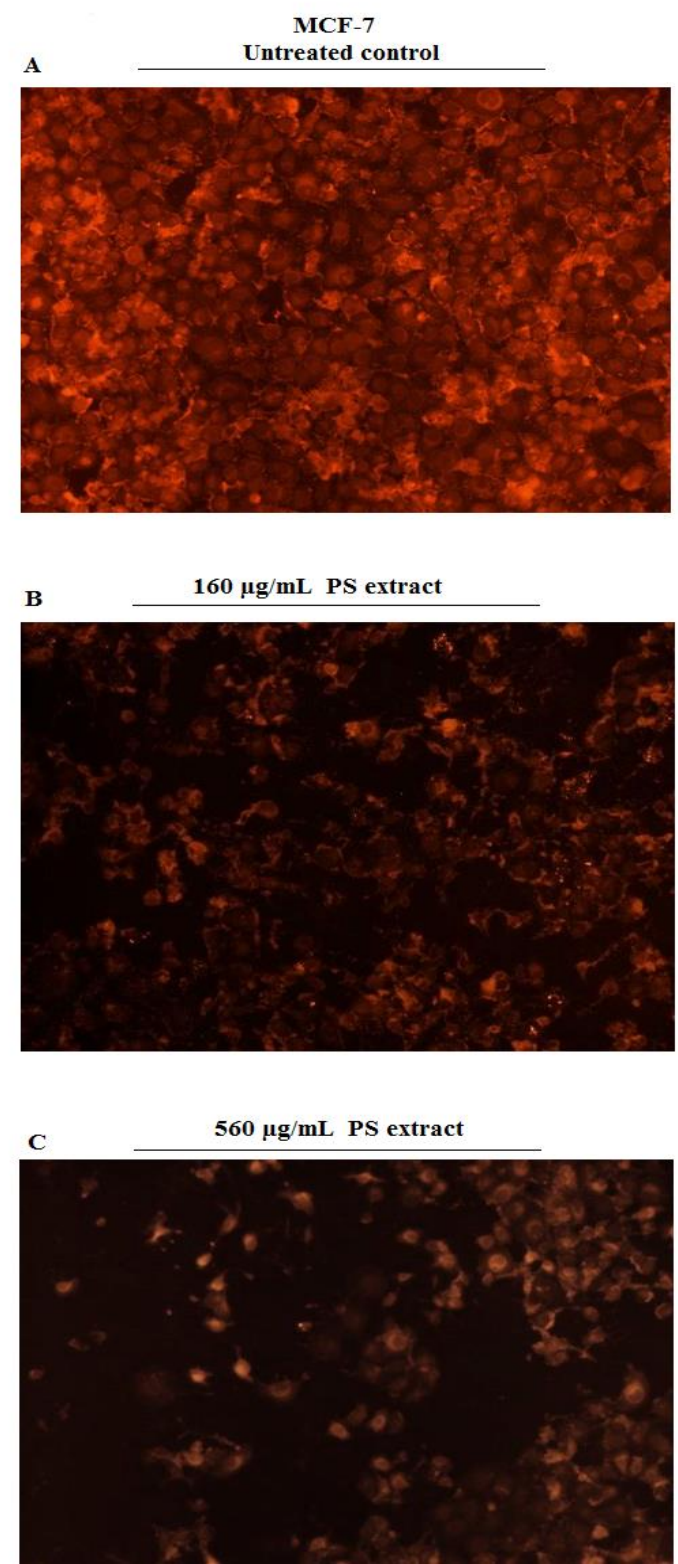

Figure 3: Analysis of the MMP after treatment with 160 $\mu \mathrm{g} / \mathrm{ml}$ and $560 \mu \mathrm{g} / \mathrm{ml}$ PS extract. Red fluorescence represents mitochondria with intact membrane potential. The mitochondria of MCF-7 cells are completely destabilized by $560 \mu \mathrm{g} / \mathrm{ml}$ extract treatment.
We further investigated the proteins involved in the apoptotic effect of PS extract. Changes in apoptosis-related protein expressions were studied by a human apoptosis array in MCF-7 breast cancer cells. Treatment of 560 $\mu \mathrm{g} / \mathrm{ml}$ PS extract for $48 \mathrm{~h}$, resulted in the reduction of Bcl2, cIAP-1, cIAP-2, Survivin and XIAP protein levels by 2.8-, 3.2-, 2.8, 2.5- and 2.2- fold in MCF-7 cells, respectively (Table 1). Moreover, PS extract treatment significantly induced Bad, Bax, Cytochrome $\mathrm{c}$ and SMAC/Diablo protein levels by 4.2-, 3.0-, 3.6-, and 4.0fold in MCF-7 cells, respectively (Table 1).

Table 1: Fold changes of apoptosis related proteins in MCF-7 cells after treatment with $560 \mu \mathrm{g} / \mathrm{ml}$ PS extract for $48 \mathrm{~h}$. The results are the mean of three independent experiments $( \pm \mathrm{SD})$.

\begin{tabular}{|c|c|}
\hline Protein name & Fold change \\
\hline Bad & $+4.2 \pm 1.0$ \\
\hline Bax & $+3.0 \pm 0.2$ \\
\hline Bcl-2 & $-2.8 \pm 0.4$ \\
\hline cIAP-1 & $-3.2 \pm 0.8$ \\
\hline cIAP-2 & $-2.8 \pm 0.4$ \\
\hline Cytochrome c & $+3.6 \pm 1.2$ \\
\hline SMAC/Diablo & $+4.0 \pm 0.8$ \\
\hline Survivin & $-2.5 \pm 0.2$ \\
\hline XIAP & $-2.2 \pm 1.2$ \\
\hline
\end{tabular}

\section{Discussion}

Plants are considered as a source of structurally diverse, bioactive compounds with specific biological activities. They have been used for therapeutic purposes due to their anti-inflammatory, antioxidant, antimicrobial, and antitumor activities [12],[13].

Pinus genus are widely distributed around the world [5]. Various parts of these trees including pine needles, cones, and pollen, are widely consumed as food or dietary supplements [4]. Some species are frequently used for their medicinal effects such as diuretic and expectorant activities. Moreover, it is used to treat diseases including pulmonary, hepatic, urinary, hypertensive disorders, hypertension, atherosclerosis, and diabetes [4], [14]. Several effective bioactive compounds have been isolated from different Pinus species including carotene, terpenoids, phenolic compounds, tannin, and alkaloids [5]. The presence of phytochemicals such as alkaloids, phenols, and terpenoids in plant extracts has been associated with the anticancer activity. Jung et al., investigated the cytotoxic effect of the distilled pine needle extracts on several cancer cells including T47D, MDA-MB-231 and MW7A breast cancer cells and SNU-354 hepatoma cells. They found that T47D and MDA-MB-231 cell lines showed lower inhibition (12\%), however, MH7A and SNU-354 
cell lines showed more inhibition $(64 \%$ and $72 \%$, respectively) by the extract treatment [15]. Hoai et al., also studied the methanol extract of Pinus sylvestris on both estrogen receptor positive and negative breast cancer cells. The needle extract inhibited all the tested breast cancer cells showing selectivity to estrogen receptor negative breast cancer cells (MDA-MB-231 with the $\mathrm{IC}_{50}$ value of 35 $\mu \mathrm{g} / \mathrm{ml}$ ) [16]. PS, the endemic variety of the Anatolian Black Pine, is one of the species of the two endemic pines in Turkey [10]. As far as we know, there is no scientific exploration of cytotoxic activity of PS extract in the literature. Thus, in this study, we evaluated the cytotoxic effect of ethanolic PS extract on MCF-7 breast cancer cells. The extract inhibited the viability of breast cancer cells in a time- and concentration-dependent manner with the $\mathrm{IC}_{50}$ value of $560 \mu \mathrm{g} / \mathrm{ml}$ at $48 \mathrm{~h}$. The higher $\mathrm{IC}_{50}$ value of the PS extract may be due to different exposure time or extraction method. Kwak et al. demonstrated that Pinus densiflora ethanolic extract inhibited the viability of KATO human gastric cancer and MCF-7 cells with the $\mathrm{IC}_{50}$ values of $209 \mu \mathrm{g} / \mathrm{ml}$ and $241 \mu \mathrm{g} / \mathrm{ml}$, respectively [5]. However, Sarvmeili et al., prepared the hydroalcoholic and phenolic extracts of Pinus eldarica and they calculated the $\mathrm{IC}_{50}$ values for HeLa and MCF-7 tumor cell lines as 0.038 and $0.032 \mu \mathrm{g} / \mathrm{ml}$, respectively, at $48 \mathrm{~h}$ [17]. Moreover, we have shown that PS extract decreased the MMP in breast cancer cells which indicate the apoptotic activity in breast cancer cells. The ability of anticancer compounds to induce apoptosis in tumor cells has become a therapeutic approach. It is demonstrated that plant extracts and compounds derived from plants may have pro-apoptotic properties and great potential for possible cancer treatment [14].

Induction of apoptosis by PS extract was found to be through inhibiting anti-apoptotic Bcl-2, cIAP-1, cIAP-2, Survivin and XIAP protein levels in breast cancer cells. Additionally, pro-apoptotic proteins such as Bad, Bax, Cytochrome $\mathrm{c}$ and SMAC/Diablo were found to be induced by the extract treatment. Similar results were obtained from other Pinus species previously. Involvement of mitochondria and related proteins in the cytotoxic effect of Pinus massoniana bark extract (PMBE) was demonstrated by Ma et al. [18]. They revealed that cytochrome c was released, the protein expressions of Bax, caspase- 9 and -3 were increased and the protein expression of Bcl-2 was decreased in PMBE-treated HeLa cells. PMBE was also tested on HepG2 human hepatoma cells and found to be apoptotic through caspase-dependent pathways. Moreover, the extract decreased the Bcl-2 protein levels in these cells [19]. Huynh and Teel found that pycnogenol extracted from the bark of Pinus maritima selectively induces apoptosis in MCF-7 human breast cancer cells [20].
This report describes the cytotoxic and apoptotic effects of endemic Pinus species on MCF-7 breast cancer cells for the first time. Although the isolation and structure elucidation of the active compounds is needed to be performed in the further studies, it is likely that PS extract may be a potential candidate for the development of novel therapeutic anticancer compounds for breast cancer. Since Turkey has such rich plant diversity, we propose that endemic plants with unrelated ethnomedicinal history might be used in throughput screens for the discovery of novel compounds for cancer therapy.

\section{Conflict of Interest}

The authors declare that they have no competing interests.

\section{References}

1. Jemal, A, Bray, F, Center, MM, Ferlay, J, Ward, E, Forman, D, Global cancer statistics. CA: A Cancer Journal for Clinicians 2011, 61, 69-90.

2. Atmaca, H, Bozkurt, E, Cittan, M, Tepe, H, Effects of Galium aparine extract on the cell viability, cell cycle and cell death in breast cancer cell lines. Journal of Ethnopharmacology 2016, 186, 305-310.

3. Wagner, HK, Wolff, PM, editors. New Natural Products and Plant Drugs with Pharmacological, Biological Or Therapeutical Activity: Proceedings of the First International Congress on Medicinal Plant Research, Section A, Held at the University of Munich, Germany, September 6-10, 1976. Springer Science \& Business Media; 2012 Dec 6.

4. Lim, UK, Yoo, JJ, Lee, JY, Pine needles. Health Care with Pine Needles 1993, 52-83.

5. Kwak, C, Moon, S, Lee, M, Antioxidant, antimutagenic, and antitumor effects of pine needles (Pinus densiflora). Nutrition and Cancer 2006, 56, 162-171.

6. Rezzi, S, Bighelli, A, Mouillot, D, Casanova, J, Composition and chemical variability of the needle essential oil of Pinus nigra subsp. laricio from corsica. Flavour and Fragrance Journal 2001, 16, 379383.

7. Li, K, Li, Q, Zhang, T, Han, Z, Li, J, Zheng, F, Procyanidins from Pinus koraiensis bark inhibits HeLa cell growth by inducing apoptosis and reducing survivin protein expression. African Journal of Biotechnology 2011, 10, 7766-7771.

8. Feng, WH, Wei, HL, Liu, G T, Effect of pycnogenol on the toxicity of heart, bone marrow and immune organs as induced by antitumor drugs. Phytomedicine :International Journal of Phytotherapy and Phytopharmacology 2002, 9, 414-418.

9. Wang, Q, Rong, Z, Teng, J, Takaishi, Y, Duan, HQ, Two new antitumor diterpenes from Pinus sylvestris. Chinese Chemical Letters 2008, 19, 187-189.

10. Sıvacıoğlu, A, Pinus nigra J. F. var. şeneriana (Saatçioğlu) Yalt. (Ebe Karaçamı)'nın Yeni Bir Yayılış Alanı. Kastamonu Üniversitesi Orman Fakültesi Dergisi 2008, 8, 97-102.

11. Alptekin, Ü, Pinus nigra arn. ssp. pallasiana lamb . holmboe var. şeneriana Saatçi.'nin yeni bir yayiliş alani. Journal of the Faculty of 
Forestry of Istanbul 1987, 37.

12. Unaldi, UE, Toroglu, S, Studies on antimicrobial activity of pyramidal black pine (Pinus nigra ssp. pallasiana var. pyramidata): an endemic plant close to become extinct. Journal of Environmental Biology 2009, 30, 197-204.

13. Kozan, E, Küpeli, E, Yesilada, E, Evaluation of some plants used in Turkish folk medicine against parasitic infections for their in vivo anthelmintic activity. Journal of Ethnopharmacology 2006, 108, 211-216.

14. Newman, D, Cragg, G, Natural products as sources of new drugs over the 30 years from 1981 to 2010. Journal of Natural Products 2012, 75, 311-335.

15. Kim, E, Jung, S, Choi, K, Ham, S, Cytotoxic effect of the pine needle extracts. Korean Journal of Food 1998, 30, 213-217.

16. Hoai, N, Duc, H, Thao, ADT, Selectivity of Pinus sylvestris extract and essential oil to estrogen-insensitive breast cancer cells Pinus sylvestris against cancer cells. Pharmacognosy Magazine 2015, 11, 290-295.

17. Sarvmeili, N, Jafarian-Dehkordi, A, Cytotoxic effects of Pinus eldarica essential oil and extracts on HeLa and MCF-7 cell lines. Research in Pharmaceutical Sciences 2016, 11, 476-483.

18. Ma, H, Lai, F, Xie, H, Wang, J, Wang, H, Involvement of the Bcl-2 family members in Pinus massoniana bark extract induced apoptosis in HeLa cells. Phytotherapy Research 2008, 22, 1472-1476.

19. Ma, H, Liu, B, Feng, D, Xie, H, Li, R, Pinus massoniana bark extract selectively induces apoptosis in human hepatoma cells, possibly through caspase-dependent pathways. International Journal of Molecular Medicine 2010, 25, 751-759.

20. Huynh, H, Teel, R, Selective induction of apoptosis in human mammary cancer cells (MCF-7) by pycnogenol. Anticancer Research 2000, 20, 2417-2420. 